\title{
PEMBENTUKAN KATA DAN ISTILAH BARU DALAM BAHASA ARAB MODERN
}

\author{
Syamsul Hadi \\ Universitas Gadjah Mada Yogyakarta, Indonesia \\ syamsulhaadi@gmail.com
}

\begin{abstract}
This paper is aimed to discuss how to produce new words and terms in Modern Standard Arabic (MSA). Due to the development of Science, Technology, and Arts, new words and terms are born. Because the new words and terms are derived from foreign languages, especially English, some methods of formation in Arabic language are needed. There are (5) five methods of this formation. Firstly, qiyâs; the use of analogy in producing new words and terms based on the Arabic rules. Secondly, isytiqâq; the use of old Arabic form to produce a new words and terms. Thirdly, translation of foreign language to Arabic. Fourtly, borrowing from foreign languages which have two categories; ta ‘îb (fully Arabization) and tadkbîl (borrowing). Fiftly, acronym/abbreviation which is newly used in Arabic language.
\end{abstract}

Keywords: $\quad$ words, term, qiyâs, isytiqâq, translation, Arabization, borrowing, acronym

\begin{abstract}
Abstrak
Artikel ini membahas pembentukan kata dan istilah baru dalam bahasa Arab Modern (Modern Standard Arabic). Akibat perkembangan berbagai bidang Ilmu Pengetahuan dan Teknologi serta Seni, terciptalah pula kata dan istilah baru. Oleh karena kata dan istilah baru tersebut berasal dari bahasa asing terutama bahasa Inggris, maka diperlukan berbagai cara pembentukannya dalam bahasa Arab. Ada 5 (lima) cara dalam pembentukan ini. Pertama, qiyâs yakni menciptakan kata dan istilah baru berdasarkan kaidah yang sudah ada. Kedua, isytiqâq yakni memanfaatkan waz̧an yang sudah ada untuk keperluan baru. Ketiga, penerjemahan dari bahasa asing ke dalam bahasa Arab. Keempat, penyerapan kata dan istilah dari bahasa asing dengan cara tå rîb (penyerapan sesuai dengan kaidah-kaidah bahasa Arab baik pengucapan maupun penulisan) dan tadkhîl (penyerapan yang tidak sepenuhnya sesuai dengan penulisan dan pengucapannya dalam bahasa Arab). Kelima, akronim/penyingkatan yang merupakan cara baru pembentukan kata dan istilah dalam bahasa Arab.
\end{abstract}

Kata Kunci: kata, istilah, qiyas, isytiqâq, terjemahan, Arabisasi, tadkhil, akronim 


\section{Pendahuluan}

Perkembangan Ilmu Pengetahuan dan Teknologi dan Seni (Ipteks) dalam berbagai bidang melahirkan kata dan istilah baru. Oleh karena negara-negara yang memimpin langkah-langkah terdepan dalam pengembangan IPTEKS kebanyakan menggunakan bahasa Inggris maka istilah-istilah baru tersebut juga merupakan kata dan istilah yang bersumber dari bahasa Inggris.

Dari sisi kebahasaan perkembangan Ipteks tersebut tentu saja berpengaruh kepada berbagai bahasa selain bahasa Inggris. Pengaruh tersebut terjadi juga dalam bahasa Arab. Tentu saja berbagai negara yang menggunakan bahasa Arab sebagai alat komunikasi resmi dan sebagai bahasa ilmu pengetahuan memerlukan strategi dan cara untuk mengikuti perkembangan Ipteks tersebut.

Bahasa Arab adalah bahasa yang mempunyai kaidah yang ketat dalam pembentukan kata yang meliputi Nomina (Ism), Verba (Fi i i), dan Partikel ( $\underline{H}$ arf). Partikel jumlahnya terbatas yakni 202 buah dan mempunyai bentuk yang tidak berubah. Adapun verba serta nomina pembentukannya selalu sesuai dengan Wazan (Form). Pembentukan-pembentukannya juga harus sesuai dengan kaidah dan wazan yang telah ada. Ahli-ahli bahasa serta lembaga-lembaga bahasa Arab selalu mempertahankan supaya semua kosa katanya selalu sesuai dengan wazan-wazan yang telah ada.

Sesuai dengan perkembangan Ipteks yang telah melahirkan kata dan istilah baru hal tersebut berpengaruh pula terhadap bahasa Arab. Pengembangan kosa kata dan istilah dalam berbagai cabang Ipteks melahirkan berbagai permasalahan kebahasaan. Bagaimana mempertahankan supaya kaidah-kaidah kebahasaan Arab dipertahankan untuk membentuk kata dan istilah baru. Selain itu bagaimanakah jika mempertahankan kaidah-kaidah bahasa Arab sulit untuk dilalukan. Apa saja cara baru yang dipakai untuk membentuk kata dan istilah baru tersebut.

Artikel ini akan mendeskripsikan bagaimanakah kaidah-kaidah serta wazanwazan yang telah ada dimanfaatkan serta kaidah-kaidah baru apa sajakah yang dipakai untuk pembentukan kata dan istilah baru di barbagai bidang Ipteks. Hasilnya akan sangat bermanfaat baik dari sisi pengembangan keilmuan serta dari sisi praktis kebahasaan akan dapat dipakai sebagai acuan di bidang kebahasaan.

Beberapa karya ilmiah telah mendeskripsikan pembentukan kata dan istilah baru dalam bahasa Arab, namun belum ada yang menganalisis dari sisi morfologis dan sintaksis terhadap pembentukan tersebut. Kitab at-Tabd₹̨̂́b fi Usbûl at-Ta rî̉ (Isa, 2002) telah merumuskan Kaidah Transliterasi untuk menuliskan huruf Latin yang dipakai untuk menuliskan bahasa Inggris. Kaidah tersebut berbeda dengan yang dirumuskan oleh Lembaga Bahasa Arab (Majma`al-Lughah al-'Arabiyyah) di Kairo.

¿Al-Ma'ajim wal Mushthalahât memaparkan hasil-hasil perumusan kaidah penyerapan dalam pembentukan istilah dari berbagai lembaga bahasa di negara-negara Arab. ${ }^{1}$ Lembaga bahasa tersebut adalah Lembaga Bahasa di Irak, Yordania, Saudi

${ }^{1}$ Chamid Shadiq Qaniby. Al-Ma âjim wa al-Mushthalabâat: Mabâhits fî al-Mushthalabâat wa al-Ma âjim wa al-Ta rî̀. (Makkah: Dâr as-Suudiyyah lin-Nasyri wa al-Tauzi`, 2000). 
Arabia, Mesir, dan Liga Arab. Karya baru tersebut tidak memberikan analisis secara kebahasaan.

'Al-Juhûd Al-Lughawiyyah' menyebutkan juga berbagai kata dan istilah baru dengan disertai contoh-contohnya. Karya ini juga tidak meberikan analisis secara morfologis maupun secara semantis. ${ }^{2}$ Kumpulan kaidah penyerapan dari bahasa asing dalam pembentukan kata dan istilah baru adalah 'Majmu'ât al-Qarârât al-Ilmiyyah fi Khamsina Aman ' menyebutkan keputusan-keputusan Lembaga Bahasa Arab di Kairo. Sesuai dengan sifatnya sebagai kumpulan keputusan-keputusan tidak disertai dengan analisis ilmiah. Untuk itulah tulisan ini di samping mendeskripsikan dengan contohcontoh yang lengkap juga akan memberikan analisis secara morfologis dan semantis.

Sejauh diketahui penelitian mengenai hal tersebut terdapat pada sebuah tulisan berjudul "Perkembangan Mutakhir dalam Bahasa Arab" (Hadi). Karya tersebut barulah sedikit memberikan contoh beberapa Wazan yang dipakai untuk pembentukan kata-kata baru. Contohnya adalah wazan Fa aâlah untuk membentuk makna alat yakni Tsallajah (kulkas) dan Sammâah (alat bantu dengar). Wazan Füâl untuk membentuk istilah penyakit misalnya Sudâ' (pusing) dan sebagainya.

Pembahasan ini mengacu pada teori penyerapan dengan berbagai aspeknya serta teori terjemahan. Haugen mengklasifikasikan penyerapan menjadi loanwords (kata serapan), loanblends (campuran serapan) atau bybrids (hibrida), dan loanshifts (geseran serapan). Loanshifts meliputi loan translations dan semantic borrowings. ${ }^{3}$

Loanwords (kata serapan), yaitu hasil importansi morfemis tanpa substitusi morfemis tetapi dengan atau tanpa substitusi fonemis. Loanblends (campuran serapan) yaitu gabungan hasil substitusi dan importansi morfemis, namun strukturnya sesuai dengan bentuk kata asing yang diserap. Loanblends ini disebut juga pungutan padu. Loanblends ini disebut juga sebagai bybrids (hibrida) yaitu campuran serapan yang strukturnya tidak sesuai dengan bentuk kata asalnya. Loanshifts (geseran serapan) yaitu hasil substitusi morfemis tanpa importasi disebut juga sebagai loan translation (terjemahan serapan).

Serapan terjemahan adalah penerjemahan langsung unsur suatu kata menjadi kata dalam bahasa yang dipinjam tanpa mengubah makna. Kridalaksana (1984:157) menyatakannya sebagai 'pinjam terjemah' (loan translation) yakni peminjaman atau peminjaman frasa dengan mempertahankan makna leksikal atau makna gramatikal aslinya, tetapi dengan mengganti morfem dan fonem-fonemnya.

Untuk membahas permasalahan berkaitan dengan pembentukan kata dan istilah di dalam bahasa Arab yang berkaitan dengan dua bahasa yaitu bahasa Inggris dan bahasa Arab, maka digunakan dua metode yakni metode distribusional (distributional method) dan metode padan (identiry method). Metode distribusional adalah metode yang penentunya adalah bagian dari bahasa yang bersangkutan. Sebaliknya,

${ }^{2}$ Muchammad Aly Az-Zarkan. Al-Jubûd al-Lughawiyyah fì Mushthalâh al-Tlm al-Hadîts. (Damaskus: Mansyûrat Ittihâd al-Kuttab al-Arab, 1994).

${ }^{3}$ Einar Haugen. Borrowing an Overview dalam William Bright. International Encyclopedia of Linguistics. (Oxford: Oxford University Press, 1992), 286. 
Arabiyât Jurnal Pendidikan Bahasa Arab dan Kebahasaaraban, 4 (2), 2017

metode padan diartikan sebagai metode yang alat penentunya di luar, terlepas, dan tidak menjadi bagian dari bahasa yang bersangkutan. ${ }^{4}$ Untuk metode padan yang digunakan adalah metode padan translasional. Metode ini digunakan untuk memadankan unsur-unsur yang dianalisa dalam bahasa Arab dengan alat pembanding unsur-unsur dari bahasa Inggris.

Berdasarkan teori dan metode tersebut di atas diketahuilah cara yang dilakukan untuk pembentukan kata dan istilah baru dalam bahasa Arab yakni dengan Qiyâs, Isytiqâq, Terjemahan, Ta rîb dan Tadkhîl, dan Akronim (Napht). ${ }^{5}$

\section{Qiyas untuk Pembentukan Kata dan Istilah Baru}

Perlu dijelaskan di sini pengertian dari kata dan istilah. Kata adalah morfem atau kombinasi morfem yang oleh bahasawan dianggap sebagai satuan lterkecil yang dapat diucapkan sebagai bentuk bebas. Adapun istilah adalah `kata atau gabungan kata yang dengan cermat mengungkapkan konsep, proses, keadaan, atau sifat yang khas daalam bidang tertentu.

Pembentukan dengan Qiyas maksudnya adalah pembentukan kata dengan mengacu kepada Wazan (Form) yang telah ada untuk keperluan baru. Acuan atau wazan untuk pembentukan kata dalam bahasa Arab ada dua pendapat yakni pendapat madzhab Kufah dan pendapat madzhab Bashrah. Madzhab Kufah berpendapat bahwa asal dari semua pembentukan kata adalah Fi il (Verba) sedangkan Madzhab Bashrah berpendapat asal dari segala pembentukan kata adalah Mashdar. ${ }^{6}$

Pendapat madzhab Kufah ini lebih populer dan hampir semua ahli bahasa Arab sampai sekarang mengikuti pemikiran madzhab Kufah ini. Semua buku Morfologi sampai sekarang tidak pernah ada yang mengikuti pendapat madzhab Bashrah. Pemikiran madzhab Bashrah hampir tidak pernah ada yang mengikutinya kecuali hanya tertera dalam khazanah teori tentang asal dari pembentukan kata.

Barulah dalam pembentukan kata dan istilah baru pada Bahasa Arab Modern (Modern Standard Arabic) pemikiran madzhab Bashrah yang berpendapat bahwa asal pembentukan kata adalah mashdar diikuti. Bahkan lebih dari itu pembentukan kata baru tidak hanya berasal dari mashdar saja akan tetapi dapat berasal dari Isim 'Adad (Numerals), Ism al-Zamân (Nouns of Place), Ism al-A yân (Concrete Noun) dan bahkan dapat berasal dari harf (Particle) serta bentuk-bentuk lain yakni pembentukan Fi il dari harf (Particle), dan Ismul-Ashwat (Noun of Sound) yang selama ini tidak pernah dilakukan.

Berikut dikemukakan beberapa kata dan istilah baru yang dibentuk dengan cara Qiyâs atau Isytiqâq, yakni:

${ }^{4}$ D. Edi-Subroto. Pengantar Metode Penelitian Linguistik Struktural. (Surakarta: Sebelas Maret University, 1992).

${ }^{5}$ Chamid Shadiq Qaniby. Al-Ma`äjim wa al-Mushthalabâat: Mabâhits fì al-Mushthalabâat wa al-Ma âjim wa al-Ta rî̉, 136.

${ }^{6}$ Abdur-Rachman Ibn Muchammad Al-Anbary. Al-Inshâf fî Masâilil-Khilâf. (Kairo: Darul Fikri, t.t.). 
Arabiyât Jurnal Pendidikan Bahasa Arab dan Kebahasaaraban, 4 (2), 2017

a. Pembentukan Fi'il (Verba) dari Isim Adad (Numerals), contohnya adalah sebagai berikut. $^{7}$

\begin{tabular}{|c|c|c|}
\hline No & Isim Adad & Kata kerja Baru \\
\hline 1 & واحد & وَحَدَ و أحد توحد (بقى وحده \\
\hline 2 & اثنان & ثنى و تثنيت (جعلته اثنين \\
\hline 3 & 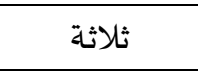 & ثلث يقال كانوا ثلاثة فربعتهم أي صرت رابعهم \\
\hline 4 & أربعة & ربع \\
\hline 5 & خمسـة & خمستهم أى صرت خامسهم \\
\hline
\end{tabular}

b. Pembentukan Fi il dari Isim Zaman (Noun of Time) ${ }^{8}$

\begin{tabular}{|c|c|c|}
\hline No & Isim Zaman & Kata Kerja Baru \\
\hline 1 & الخريف & أفعل - أخرف (دخلوا في الخريف) \\
\hline 2 & 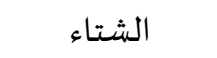 & تفعل - تشــيت (أقمت به في الشتاء) \\
\hline 3 & 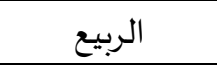 & أفعل - أربع القوم (دخلوا فى الربيع) \\
\hline 4 & الصيف & أصاف القوم (دخلوا فى الصيف) \\
\hline
\end{tabular}

c. Pembentukan Fìil (Verba) dari Ismul A yân (Concrete Noun) ${ }^{9}$

\begin{tabular}{|c|c|c|}
\hline $\mathrm{No}$ & Ismul A yan & Kata Kerja Baru \\
\hline 1 & الأمكنة: الحرام & أحرم القوم أي دخلوا في الحرام \\
\hline 2 & الشرق & شرقوا (دهبوا إلى الشرق) \\
\hline 3 & أسماء الأقارب الأب & أبوت أو أبيت صرت أبا \\
\hline 4 & أعضياء الجسم الإبط & تأبط (وضعته تحت إبطه) -أدناه أى ضرب أدناه \\
\hline 5 & 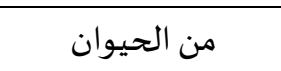 & استأسـد و تنمر من النمر واستنوق من الناقة \\
\hline
\end{tabular}

d. Pembentukan Fi il (Verba) dari beberapa hal: ${ }^{10}$

\begin{tabular}{|c|c|c|}
\hline $\mathrm{No}$ & Asal & Kata Kerja Baru \\
\hline 1 & جيس الجيوش & طلب مناه جيشا الجيوش \\
\hline 2 & حبل & حبل الشىء حبلا شـده بالحبل \\
\hline
\end{tabular}

${ }^{7}$ Chamid Shadiq Qaniby. Al-Ma âjim wa al-Mushthalabâat: Mabâhits fî al-Mushthalabâat wa al-Ma âjim wa al-Ta rî̀, 143.

${ }^{8}$ Chamid Shadiq Qaniby. Al-Ma`äjim wa al-Mushthalabâat: Mabâhits fî al-Mushthalabâât wa al-Ma âjim wa al-Tairîb, 144.

${ }^{9}$ Chamid Shadiq Qaniby. Al-Ma`âjim wa al-Mushthalabât: Mabâhits fî al-Mushthalabâât wa al-Ma âjim wa al-Ta rîb, 143.

${ }^{10}$ Chamid Shadiq Qaniby. Al-Ma âjim wa al-Mushthalabâat: Mabâhits fì al-Mushthalabâat wa al-Ma âjim wa al-Ta rî̉, 145. 
Arabiyât Jurnal Pendidikan Bahasa Arab dan Kebahasaaraban, 4 (2), 2017

e. Pembentukan Fìil dari Isim Ashwath (Noun of Sound) ${ }^{11}$

\begin{tabular}{|c|c|c|}
\hline $\mathrm{No}$ & Ismul Ashwât & Kata Kerja Baru \\
\hline 1 & جأجأ & زجرابل بالقول جؤجؤ \\
\hline 2 & سأسأ & في زجر الحمار \\
\hline 3 & حاحيت & من حاء \\
\hline 4 & عاعيت & من عين \\
\hline 5 & هاهيت & من هاء \\
\hline
\end{tabular}

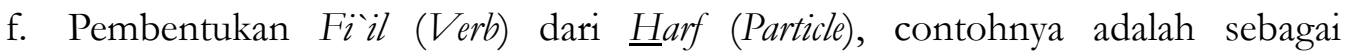
berikut. $^{12}$

\begin{tabular}{|c|c|c|}
\hline No & Charf & Kata Kerja Basru \\
\hline 1 & من لولا \\
\hline 2 & من سوف & \\
\hline
\end{tabular}

g. Pembentukan Isim (Noun) dari Adat/ $\underline{\text { Harf }}$ (Particle) cara ini belum pernah dilakukan sebelumnya ${ }^{13}$

\begin{tabular}{|c|c|c|}
\hline No & Adat & Nomina Baru \\
\hline 1 & النعم والنحن والهنا & \\
\hline 2 & الغيرية والفوقية والتحتية & \\
\hline
\end{tabular}

\section{Isytiqâq Untuk Pembentukan Kata dan Istilah Baru}

Isytiqâq adalah pemanfaatan wazan-wazan yang telah ada untuk pembentukan Kata dan Istilah Baru. Adapun wazan-wazan tersebut adalah sebagai berikut. ${ }^{14}$

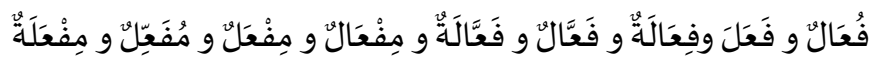

Contoh untuk masing-masing adalah sebagai berikut.

a. Wazan فُعَالْ untuk membentuk istilah penyakit, contohnya:

\begin{tabular}{|c|c|}
\hline Kata/Istilah Asing & Kata/Istilah Arab \\
\hline posthitis & قلاف \\
\hline rhinitis & أناف \\
\hline
\end{tabular}

${ }^{11}$ Chamid Shadiq Qaniby. Al-Ma âjïm wa al-Mushthalabât: Mabâhits fî al-Mushthalahâat wa al-Ma âjim wa al-Ta rîb, 145.

${ }^{12}$ Chamid Shadiq Qaniby. Al-Ma âjïm wa al-Mushthalahâat: Mabâhits fî al-Mushthalahât wa al-Ma âjïm wa al-Ta rîb, 145.

13 Chamid Shadiq Qaniby. Al-Ma ‘äjim wa al-Mushthalahâat: Mabâhits fî al-Mushthalahâat wa al-Ma âjïm wa al-Ta rîb, 145.

14 Syamsul Hadi. Glosarium Kata dan Istilah Asing dalam Bahasa Arab. (Yogyakarta: Seksi Penerbitan Jurusan Sastra Asia Barat FIB UGM, 2005), 13-16. Lihat juga Mamduh Muhammad Khasarah, 'Ilm al-

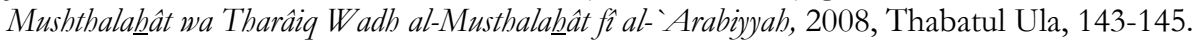


Arabiyât Jurnal Pendidikan Bahasa Arab dan Kebahasaaraban, 4 (2), 2017

\begin{tabular}{|c|c|}
\hline schizophrenia & فصام \\
\hline sclerotitis & صلاب \\
\hline stillbirth & بلاص \\
\hline
\end{tabular}

b. Waz̧an فَعَلَ (verba) untuk membuat istilah penyakit, contohnya: ${ }^{15}$

\begin{tabular}{|c|c|}
\hline Kata/Istilah Asing & Kata/Istilah Arab \\
\hline chilblain & شرب \\
\hline exostosis & عرن \\
\hline ophthalmia & رمد \\
\hline psoriasis & حصف \\
\hline rabies & كلب \\
\hline
\end{tabular}

c. Wazan فِ فِعَالَةٌ untuk membentuk istilah tentang pekerjaan/profesi, contohnya: ${ }^{16}$

\begin{tabular}{|c|c|}
\hline Kata/Istilah Asing & Kata/Istilah Arab \\
\hline journalism & صحافة \\
\hline shipping & وراقة \\
\hline stationery & aفانة \\
\hline
\end{tabular}

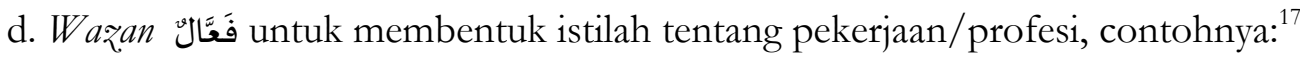

\begin{tabular}{|c|c|}
\hline Kata/Istilah Asing & Kata/Istilah Arab \\
\hline florist & زهار \\
\hline lionist & أساد \\
\hline pilot & نمار \\
\hline surgeon & جيار \\
\hline tigrist & contohngan \\
\hline
\end{tabular}

e. Wazan فَسَّالَُّ untuk membentuk istilah peralatan, contohnya: ${ }^{18}$

\begin{tabular}{|c|c|}
\hline Kata/Istilah Asing & Kata/Istilah Arab \\
\hline beadphone & سماعة ثلاجة غسالة \\
\hline refrigerator & washing machine \\
\hline
\end{tabular}

15 Syamsul Hadi. Glosarium Kata dan Istilah Asing dalam Bahasa Arab, 13.

16 Syamsul Hadi. Glosarium Kata dan Istilah Asing dalam Bahasa Arab, 14.

17 Syamsul Hadi. Glosarium Kata dan Istilah Asing dalam Bahasa Arab, 15.

18 Syamsul Hadi. Glosarium Kata dan Istilah Asing dalam Bahasa Arab, 16. 
Arabiyât Jurnal Pendidikan Bahasa Arab dan Kebahasaaraban, 4 (2), 2017

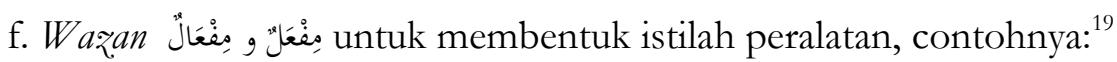

\begin{tabular}{|c|c|}
\hline Kata/Istilah Asing & Kata/Istilah Arab \\
\hline bygrometre & مرطب مجهار \\
\hline microscope & مجسام \\
\hline sterioscope & مسماعب \\
\hline stethoscope & clemetre \\
\hline
\end{tabular}

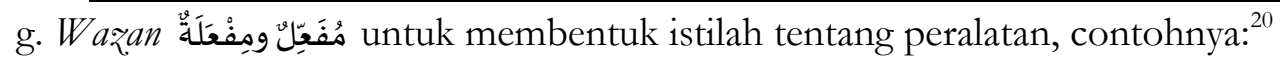

\begin{tabular}{|c|c|}
\hline Kata/Istilah Asing & Kata/Istilah Arab \\
\hline amplifier & مكبر \\
\hline analyser & محلل \\
\hline condenser & مكثف \\
\hline generator & مولد \\
\hline transformer & محول \\
\hline
\end{tabular}

h. Wazan فَعَالْة untuk menerjemahkan sufiks logy yang menunjukkan arti ilmu, contohnya adalah sebagai berikut. ${ }^{21}$

\begin{tabular}{|c|c|}
\hline الألفاظ الإنجيليزية & المصطلحات العربية الجديدة \\
\hline ethnology & رساسة \\
\hline genealogy & نسابة \\
\hline adontology & ضراسة \\
\hline apeleology & كهافـة \\
\hline urinology & بوالة \\
\hline
\end{tabular}

i. Selain itu didapatkan pembentukan verba dari verba bahasa Inggris, dengan memanfaatkan wazan فَعْلَلَ contohnya adalah sebagai berikut. ${ }^{22}$

\begin{tabular}{|c|c|}
\hline Verba Bahasa Inggris & Setelah Terserap dalam Bahasa Arab \\
\hline acclimate & يؤقلم يبكلز \\
\hline anglicize & يتلفن \\
\hline bacterize & يلفن \\
\hline balkanize & \\
\hline telephone & \\
\hline
\end{tabular}

${ }^{19}$ Syamsul Hadi. Glosarium Kata dan Istilah Asing dalam Bahasa Arab, 15.

${ }^{20}$ Syamsul Hadi. Glosarium Kata dan Istilah Asing dalam Bahasa Arab, 16.

${ }^{21}$ Syamsul Hadi. Glosarium Kata dan Istilah Asing dalam Bahasa Arab, 16.

22 Syamsul Hadi. Glosarium Kata dan Istilah Asing dalam Bahasa Arab, 16. 


\section{Terjemahan untuk Pembentukan Kata dan Istilah Baru}

Adapun penerjemahan dari bahasa asing terutama adalah penerjemahan berbagai As-Sawâbiq (prefiks) dan Lawâhiq (sufiks) dari bahasa Inggris ke dalam bahasa Arab. Terjemahan yang penting untuk dikemukakan di sini adalah terjemahan a Y-lasiqul-qabliy (prefiks) dan a'l-lasiqul-ba'diy (sufiks). ${ }^{23}$

a. Prefiks mono, diterjemahkan dengan kata Arab uhadi (أحادى) contohnya adalah ${ }^{24}$

\begin{tabular}{|c|c|}
\hline monofonemic & أحادى الفونيم أحادى الصيوت \\
\hline monofonis & أحادى اللغة \\
\hline monoglot & أحادى المرفيم المعنى \\
\hline monofonemic & أحادى \\
\hline monosemy & أحاديم \\
\hline
\end{tabular}

b. Prefiks post diterjemahkan dengan khalfi sebagai ajektif, contoh $^{25}$ :

\begin{tabular}{|c|c|}
\hline post-vocalic & الصائتى الخلفى \\
\hline post-alvedar & اللثوى الخلفى \\
\hline post-dental & الأسنانى الخلفى \\
\hline post-glacial & الجلدى الخلفى \\
\hline post-palatal & الحنكى الخلفى \\
\hline
\end{tabular}

c. Prefiks inter diterjemahkan dengan baina misalnya ${ }^{26}$ :

\begin{tabular}{|c|c|}
\hline inter-vocalic & بين الصائتى \\
\hline inter-consonantal & بين الصيامتى \\
\hline inter-dental & بين الأسنانى \\
\hline Interlud & بين الصائتى \\
\hline Internal & بين الصيائتية \\
\hline
\end{tabular}

d. Prefiks sub diterjemahkan dengan far'i atau tablyty sebagai ajektif, misalnya:

\begin{tabular}{|c|c|}
\hline subcategorization & التصنيف التفريعى \\
\hline subclausa & العبارة الفرعية العبقة التحتية \\
\hline substratum & اللهجة الفرعية الفرعية \\
\hline subrelationship & الفرية \\
\hline subdialect &
\end{tabular}

${ }^{23}$ Ja’far Dak Al-Baab. "Al-Shawâmit wa al-Shawâit fî al-'Arabiyyah”, Al-Lisânul-Arabi, Nomor 29, 1982. Lihat juga F.M. Abdur Rachman. Ad-Dakhîl fì al-Lughah al-'Arabiyyah wa Labjâtihâ, (Madinah: t.t., 1975).

${ }^{24}$ Syamsul Hadi. Glosarium Kata dan Istilah Asing dalam Bahasa Arab, 5.

${ }^{25}$ Syamsul Hadi. Glosarium Kata dan Istilah Asing dalam Bahasa Arab, 5-6.

${ }^{26}$ Syamsul Hadi. Glosarium Kata dan Istilah Asing dalam Bahasa Arab, 6. 
Arabiyât Jurnal Pendidikan Bahasa Arab dan Kebahasaaraban, 4 (2), 2017

e. Prefiks poli diterjemahkan dengan muta'addid, misalnya ${ }^{27}$ :

\begin{tabular}{|c|c|}
\hline polisilabic & متعدد المقاطع \\
\hline polisistemic & متعدد النظمة \\
\hline polisindenton & متعدد التركيب \\
\hline polisemy & متعدد المعانى \\
\hline poliglot & متعدد اللغات \\
\hline
\end{tabular}

f. Prefiks non-, im, dan anti diterjemahkan dengan ghairu, seperti ${ }^{28}$ :

\begin{tabular}{|c|c|}
\hline non-sentence & غير الجملة غير المقطي \\
\hline non-syllabic & غير الشخيائتي الشحوي \\
\hline غيري & \\
\hline impersonal & \\
\hline antigrammatical (non-gramatical) & \\
\hline
\end{tabular}

g. Prefiks bi diterjemahkan denga tsani, contohnya antara lain ${ }^{29}$ -

\begin{tabular}{|c|c|}
\hline bicarbonate & ثانى كربونات \\
\hline bitartate & ثانى طرطرات كرومات \\
\hline bichromate & (t) dam \\
\hline
\end{tabular}

h. Kata-kata lain yang tersusun dari dua unsur terjemahannya ke dalam bahasa Arab dipisahkan, contohnya antara lain ${ }^{30}$ :

\begin{tabular}{|c|c|}
\hline dorso-velar & طبقي خلقى \\
\hline apico-interdental & بيأسـنانى ذلقى \\
\hline apico-alveolar & لثوى ذلقى \\
\hline apico-labial & شفوى ذلقى \\
\hline palato-alveolar & ل لثوى غارى \\
\hline
\end{tabular}

i. Sufikas logy dan graphy diterjemahkan dengan lujiza dan grafiya. Contohnya adalah sebagai berikut ${ }^{31}$ :

\begin{tabular}{|c|c|}
\hline Anthropology & الأنتروبولوجيا \\
\hline Philology & الفيلولوجيا \\
\hline Phonology & الفونولوجيا \\
\hline
\end{tabular}

${ }^{27}$ Syamsul Hadi. Glosarium Kata dan Istilah Asing dalam Bahasa Arab, 5.

${ }^{28}$ Syamsul Hadi. Glosarium Kata dan Istilah Asing dalam Bahasa Arab, 7.

${ }^{29}$ Syamsul Hadi. Glosarium Kata dan Istilah Asing dalam Bahasa Arab, 7.

${ }^{30}$ Syamsul Hadi. Glosarium Kata dan Istilah Asing dalam Bahasa Arab, 7.

${ }^{31}$ Syamsul Hadi. Glosarium Kata dan Istilah Asing dalam Bahasa Arab, 8. 
Ara6iyât Jurnal Pendidikan Bahasa Arab dan Kebahasaaraban, 4 (2), 2017

\begin{tabular}{|c|c|}
\hline Physiography & الفيزيوغرافيا \\
\hline Anthropography & النتروفوغرافيا \\
\hline
\end{tabular}

j. Sufiks -ism dan -ics diterjemahkan dengan iyyah, contohnya adalah sebagai berikut.

\begin{tabular}{|c|c|}
\hline Bilingualism & الثنائية اللغوية \\
\hline Existensialism & الوجودية الكحولية \\
\hline Alkoholisme & السياسية \\
\hline Economics & الكتيادية \\
\hline Politics & الكياد \\
\hline
\end{tabular}

k. Sufiks -ist dan -er diserap dengan penambahan $y \hat{a}$ ' nisbah sebagai contoh antara lain:

\begin{tabular}{|c|c|}
\hline Pathologis & الباتولوجيا \\
\hline Philologist & الفيلولوجيا \\
\hline Petrologist & البترولوجيا \\
\hline Paleographer & البليوغرافى \\
\hline Physiographer & الفيزيوغرافي \\
\hline
\end{tabular}

1. Ajektiva dengan sufiks -an, -ic, dan -al serta -ive diterjemahkan dengan penambahan yâ' nisbah, misalnya ${ }^{32}$ :

\begin{tabular}{|c|c|}
\hline Macedonian & مقدونى \\
\hline Pathologic & باتولوجى \\
\hline Physiologic & فسيولوجى \\
\hline Phenomenological & الفينومينولوجى \\
\hline Philological & الفيلولوجى \\
\hline
\end{tabular}

m. Tarkîb idhâfí dimanfaatkan juga dalam terjemahan, contohnya: ${ }^{3.3}$

\begin{tabular}{|c|c|}
\hline الألفاظ الإنجيليزية & المصطلحات العربية الجديدة \\
\hline anemograph & مرسمة الريح \\
\hline barograph & مرسمة الضغط \\
\hline chromograph & مرسمة السرعة \\
\hline electograph & مرسمة كهربية \\
\hline thermograph & مرسمة الحرارة \\
\hline
\end{tabular}

Selain itu ditemukan juga terjemahan beberapa istilah. Dari pengamatan terhadap penerjemahan ternyata masih merupakan sebuah upaya baik dari lembaga

${ }^{32}$ Syamsul Hadi. Glosarium Kata dan Istilah Asing dalam Bahasa Arab, 8.

33 Syamsul Hadi. Glosarium Kata dan Istilah Asing dalam Bahasa Arab, 5. 
Arabiyât Jurnal Pendidikan Bahasa Arab dan Kebahasaaraban, 4 (2), 2017

bahasa yang ada serta para ahli bahasa (rijal al-lughah) dan para leksikograf yang masih perlu diseragamkan. Bukti bahwa terjemahan masih harus dilakukan penyeragaman yakni terdapatnya terjemahan kata Phonology dengan beberapa istilah, yakni: ${ }^{34}$

\begin{tabular}{|c|c|}
\hline No. & Terjemahan dalam Bahasa Arab \\
\hline 1. & علم الأصيوات التنظيمى، فونولوجيا \\
\hline 2. & علم التشكيل الصيوتى \\
\hline 3. & علم وظائف الأصيوات \\
\hline 4. & النطقيات (فونولوجيا ) \\
\hline 5. & علم الأصيوات \\
\hline 6. & فونولوجي \\
\hline 7. & الفونولوجيا (دراسة الألفاظ اللغوية فى لغة ما) \\
\hline 8. & علم وظائف الأصوات \\
\hline 9. & علم الأصوات التشكيلى \\
\hline 10. & علم النظم الصوتية \\
\hline 11. & الفونولوجيا (علم الأصوات اللغوية الوظيفى \\
\hline 12. & دراسـة اللفظ الوظيفى، فونولوجيا \\
\hline
\end{tabular}

\section{Penyerapan untuk Pembentukan Kata dan Istilah}

Ada beberapa kaidah yang dipakai untuk menuliskan kata dan istilah asing yang diserap ke dalam bahasa Arab. Dalam pembahasan ini akan dikutip kaidah alih tulis Arab-Latin yang dirumuskan oleh Lembaga Bahasa Arab di Kairo sebagai berikut. ${ }^{35}$ Kaidah alih tulis tersebut dapat diketahui dari tabel sebagai berikut.

Tabel 1

Kaidah Alih Tulis Latin-Arab

\begin{tabular}{|c|c|c|c|}
\hline No & Huruf Latin & \multicolumn{2}{|c|}{ Huruf Arab Yang Sesuai } \\
\hline \multirow{3}{*}{1} & \multirow{3}{*}{ c } & \multicolumn{2}{|c|}{ ق س ك. } \\
\hline & & arcadia & أرقاديا \\
\hline & & carbon & كاربون \\
\hline \multirow{2}{*}{2} & \multirow{2}{*}{ d } & \multicolumn{2}{|c|}{ د د } \\
\hline & & dioteles & ذيو طاليس \\
\hline
\end{tabular}

34 Muchammad Chilmy Hulayyil. "Al-Mushthalâhu al-Shautî baina al-Ta'tîb wa al-Tarjamah", dalam Al-Lisânul-'Arabî, Nomor 21, 1982, 105.

35 Mamduh Muhammad Khasarah. Tlm al-Mushthalabât wa Tharâiq Wadh al-Musthalahât fì alArabiyyah, 272-277. 
Arabiyât Jurnal Pendidikan Bahasa Arab dan Kebahasaaraban, 4 (2), 2017

\begin{tabular}{|c|c|c|c|}
\hline & & laodice & 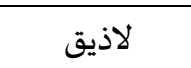 \\
\hline \multirow{3}{*}{3} & \multirow{3}{*}{$\mathrm{f}$} & \multicolumn{2}{|c|}{ ( } \\
\hline & & festus & فسطوس \\
\hline & & France & أفرنسـة \\
\hline \multirow{2}{*}{4.} & \multirow{2}{*}{$\mathrm{g}$} & \multicolumn{2}{|c|}{ ج } \\
\hline & & galatia & 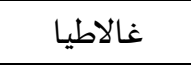 \\
\hline \multirow{2}{*}{5.} & \multirow{2}{*}{$\mathrm{h}$} & \multicolumn{2}{|c|}{ ه } \\
\hline & & balogen & هالوجين \\
\hline \multirow{3}{*}{6.} & \multirow{3}{*}{$\mathrm{ch}$} & \multicolumn{2}{|c|}{ خ ك تش } \\
\hline & & chemistry & كيمياء \\
\hline & & chrisoline & خريسولين \\
\hline \multirow{4}{*}{7.} & \multirow{4}{*}{ j } & \multicolumn{2}{|c|}{ ي } \\
\hline & & jovinianus & يوبنيانوس \\
\hline & & juvenalis & يوبنالس \\
\hline & & julianus & يوليانس \\
\hline \multirow{4}{*}{8.} & \multirow{4}{*}{$\begin{array}{c}\mathrm{ph} \\
\mathrm{P}\end{array}$} & \multicolumn{2}{|c|}{ ف ب } \\
\hline & & porphyrius & فورفوريوس \\
\hline & & pelaton & أفلاطون \\
\hline & & Philippus & فليفوس \\
\hline \multirow{4}{*}{9} & \multirow{4}{*}{$\mathrm{k}$} & \multicolumn{2}{|c|}{ ك,ق } \\
\hline & & peri kineseon & فارى قينساون \\
\hline & & leukemia & 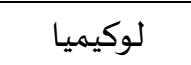 \\
\hline & & kaliduim & قَليديوم \\
\hline \multirow{4}{*}{10} & \multirow{4}{*}{$q$} & \multicolumn{2}{|c|}{ ك نقل(ق) } \\
\hline & & qwinttus & قونطوسفي \\
\hline & & attique & أطيقي \\
\hline & & quintus & قنطوس \\
\hline \multirow{4}{*}{11} & \multirow{4}{*}{$\mathrm{t}$} & \multicolumn{2}{|c|}{ Dipindahkan menjadi (b) } \\
\hline & & titus & طيطوسـي \\
\hline & & timéé & طيماوس \\
\hline & & antipater & أنطيفطر \\
\hline 12 & th & & \\
\hline
\end{tabular}


Arabiyât Jurnal Pendidikan Bahasa Arab dan Kebahasaaraban, 4 (2), 2017

\begin{tabular}{|c|c|c|c|}
\hline & & cithaeron & ق ق قيثرون \\
\hline \multirow{4}{*}{13} & \multirow{4}{*}{$\mathrm{s}$} & \multicolumn{2}{|c|}{ س، ش، ص } \\
\hline & & Socrate & سقراط \\
\hline & & sclave & صقلاب \\
\hline & & crétes & اقريطش \\
\hline \multirow{4}{*}{14} & \multirow{4}{*}{$\mathrm{V}$} & \multicolumn{2}{|c|}{ وب ق } \\
\hline & & novatus & ناباطس \\
\hline & & juvenalis & يوبنالس \\
\hline & & sévéres & سورس \\
\hline \multirow{2}{*}{15} & \multirow{2}{*}{$\mathrm{W}$} & \multicolumn{2}{|c|}{ و- ث } \\
\hline & & volkswagen & فولكس واجن \\
\hline \multirow{4}{*}{16} & \multirow{4}{*}{$\mathrm{x}$} & كس, ك, س, كز, خ & \\
\hline & & anaximenes & أنكسيمانس \\
\hline & & anaxagoras & أنكساغورس \\
\hline & & $d u x$ & دوقس \\
\hline \multirow{2}{*}{17} & \multirow{2}{*}{$\mathrm{Z}$} & \multicolumn{2}{|c|}{ 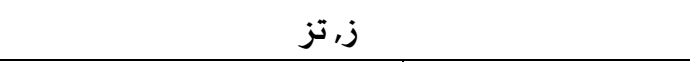 } \\
\hline & & zenon & زينون \\
\hline
\end{tabular}

Untuk penyerapan dari bahasa asing (Inggris) diserap kemudian dibentukdengan kaidah bahasa Arab sehingga terjadilah bentuk hibrid asing dan Arab. Kata yang berakhir dengan sufiks -ist dan - er diserap dan ditambahkan ya' nisbah, sebagai contoh adalah:

\begin{tabular}{|c|c|}
\hline Pathologis & الباتولوجيا \\
\hline Phenomenologist & الفينومينولوجيا الفيلولوجيا \\
\hline Philologist & البليوولوجيا \\
\hline Petrologist & الفيزيوغرافى \\
\hline Paleographer & Physiographer \\
\hline
\end{tabular}

Contoh lain bentuk hibrida ini adalah ajektiva yang berakhir dengan sufiks -an, -ic, dan -al serta -ive diserap dengan penambahan ya' nisbah, misalnya:

\begin{tabular}{|c|c|}
\hline Maccabean & مقدونى مكابى \\
\hline Macedonian & مليتونى \\
\hline Nepturian & Malpighian \\
\hline
\end{tabular}


Arabiyât Jurnal Pendidikan Bahasa Arab dan Kebahasaaraban, 4 (2), 2017

\begin{tabular}{|c|c|}
\hline Althaic & الطائى \\
\hline Anemic & أنيمى \\
\hline Apochromatic & أبوكروماتى \\
\hline Pathologic & باتولوجى \\
\hline Physiologic & فسيولوجى \\
\hline Phenomenological & الفينومينولوجى \\
\hline Philological & الفيلولوجى \\
\hline
\end{tabular}

Contoh-contoh berikut ini adalah kata dan istilah serapan dari bahasa Inggris yang diklasifikasikan dalam dua jenis, yakni al-mu'arrab dan ad-dakhîl. Disebut mu'arrab adalah yang sudah diserap ke dalam bahasa Arab dibentuk sesuai dengan wazan yang ada dalam bahasa Arab. Adapun ad-dakhîl maksudnya adalah kata-kata yang dipinjam dan tidak dapat dibentuk dengan wazan yang ada di dalam bahasa Arab. Contoh keduanya dapat dilihat dalam tabel berikut ini. ${ }^{36}$

Tabel 2

Kata-kata dari Bahasa Inggris; Muarrab dan Dakhîl

\begin{tabular}{|c|c|c|c|}
\hline Kata Asing & Kata Terserap & Wazan & Jenis Pungutan \\
\hline Acetyle & أَسِتيل & فِعِيْلِيْل & معرب \\
\hline Aminé & أَميني - حمض & فِعِيْلي & معرب \\
\hline Arachidonique & أَراكيدونيك & - & دخيل \\
\hline Ascorbique & أَسكوْرْبك & - & دخيل \\
\hline Aspartique & أَسْنبَبرتَتيك & فَعْلَلَّيل & معرب \\
\hline Benzö̈que & بَنْزَويك & فَعْلَويل & معرب \\
\hline Borique & بُوريك & فُوعيل & معرب \\
\hline Caprique & كَبْرْيك & فَعْليل & معرب \\
\hline Caproique & كَبْرَوَك & فَعْلَويل & معرب \\
\hline Carbonique & كَرْبُونيك & فَعْلُوليل & معرب \\
\hline Bureaucratie & بيروقُطيّة & - & دخيل \\
\hline Woorkshop & وَزْشَة & - & معرب \\
\hline Ecologie & إيكولوجْيَة & - & دخيل \\
\hline Morphologie & مورفولوجْيَة & & دخيل \\
\hline Technologie & تكُنْولوُجْيا & - & دخيل \\
\hline
\end{tabular}

36 Mamduh Muhammad Khasarah. Ilm al-Mushthalahât wa Tharâiq Wadh al-Musthalabât fì alArabiyyah, 372-375. 
Arabiyât Jurnal Pendidikan Bahasa Arab dan Kebahasaaraban, 4 (2), 2017

\begin{tabular}{|c|c|c|c|}
\hline Democratie & ديمُوقُرطيّة & مصيدر صناعي & معرب \\
\hline Electron & إِلِكتُرون & فِعِلِّول & معرب \\
\hline Batterie & بطّاريّة & فَعَّاليّة & معرب \\
\hline Cathode & كاثود & فاعول & معرب \\
\hline Electrode & إِلكِتْرود & فِعِلِلّول & معرب \\
\hline Anode & أَنْود & فَعول & معرب \\
\hline Transistor & ترانزُستور & - & دخيل \\
\hline Dynatron & ديناتْرون & - & دخيل \\
\hline Dynode & دايْنود & - & دخيل \\
\hline Gas & غاز & فَعْلْ & معرب \\
\hline Oscilographe & أُسيلوجْراف & - & دخيل \\
\hline Empiéme & أَمبيما & فعليلى & معرب \\
\hline Ataxie & أَتاكُسْيَا & - & دخيل \\
\hline Athrepsie & أَتَتْبْسِيا & فعلليل & معرب \\
\hline Arctium & أَرْقَطَيْون & فَعْلَلْيُول & معرب \\
\hline Hypo-test & احتبار الهِيْبُو & فَعْلُو & معرب \\
\hline Aréometer & أَرِيُومِتْر & فَعْيُولل & معرب \\
\hline Azides & أزيدات & فعيلات & معرب \\
\hline Aspestos & أَسْبِسِتْتُوس & فَعْلِلّول & معرب \\
\hline Ascleroscope & إِسنكلْيروسنكوب & - & دخيل \\
\hline Sclemetre & إِسْكُليروُمتر & - & دخيل \\
\hline Acyle & أَسيل & فَعيل & معرب \\
\hline Actode & أَكْكْتود & فَعْلُول & معرب \\
\hline Ichthyole & إكِتْيُول & فِعْلِيول & معرب \\
\hline Electrophorus & إِلِكِيتُروفور & - & دخيل \\
\hline Alkylation & أَلَكَكَلَة & فَعْلَلَة & معرب \\
\hline Cetane & سِيْتين & فعليل & معرب \\
\hline Silica & سِيْليكا & فِيعيلا & معرب \\
\hline Raton & الراتون & فاعُول & معرب \\
\hline Sulphitation & السيّلْفَتَة & فَعْلَلة & معرب \\
\hline Brass & البَراص & فَعَال & معرب \\
\hline Brushe & البرشة & فَعْلَة & معرب \\
\hline
\end{tabular}


Ara6iyât Jurnal Pendidikan Bahasa Arab dan Kebahasaaraban, 4 (2), 2017

\begin{tabular}{|c|c|c|c|}
\hline Tennis & التَّنْس & فِعْل & معرب \\
\hline Nitrification & نَتَرَيَة & فَعْلَلَة & 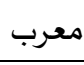 \\
\hline Sputnik & سُبِودْنك & - & دخيل \\
\hline Epistémologie & إِِسنمُولوجْيـا & - & دخيل \\
\hline Ethnographie & إتْنْوغْرافيا & - & دخيل \\
\hline Ethnologie & إتْنُولوجْيا & - & دخيل \\
\hline Aristrocratie & أَرِسنتُقْراطيّة & مصيدر صناعي & معرب \\
\hline Académie & أَكاديمْيا & - & دخيل \\
\hline Eon & أََيُون & فَعُول & معرب \\
\hline Pragmatisme & براغماتية & - & دخيل \\
\hline Bourgeaisie & بُبْجُوازيّة & مصدر صناعي & معرب \\
\hline Praxis & بْرَكُسيس & - & دخيل \\
\hline Pyrhonisme & بيْرونِيّة & مصدر صناعي & معرب \\
\hline Episeméme & إبـسييم & فِعْلِيليل & معرب \\
\hline Apostrophe & أبوسنتروف & - & 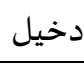 \\
\hline Idiophone & إِدْيُوفون & فعيولول & معرب \\
\hline Ideographe & إدْيُوكَراف & - & دخيل \\
\hline Ideogram & إذِيوكََرام & - & دخيل \\
\hline Atlas & الأطلس & فَعْلَلَ & معرب \\
\hline Acrophony & أَكُرُوفُونْيا & - & دخيل \\
\hline Acostic & أَكوسنتي & - & دخيل \\
\hline Acausma & أَكُوسنما & - & دخيل \\
\hline Allo & أَلَُّوا & فَعْلو & 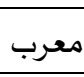 \\
\hline Abélie & أَبيلية & فَعيلية & معرب \\
\hline Aberia & أَبيِِيَة & فعيلية & معرب \\
\hline
\end{tabular}

Dari kolom ke-4 tabel tersebut di atas dapat diketahui bahwa ada kata dan istilah yang muarrab (disesuaikan dengan wazan yang ada dalam bahasa Arab) dan dakhill (penyerapan kata yang tidak sepenuhnya sesuai dengan wazan yang ada di dalam bahasa Arab).

\section{Singkatan dan Akronim untuk Pembentukan Kata dan Istilah}

Semua kata dalam bahasa Arab selalu sesuai dengan waz̧an-waz̧an yang ada. Jika sebuah kata atau istilah menyimpang dari wazan yang ada kemungkinannya adalah kata serapan dari bahasa asing. Dalam perkembangannya pada masa kini dalam Arab 
Arabiyât Jurnal Pendidikan Bahasa Arab dan Kebahasaaraban, 4 (2), 2017

mengalami perkembangan sehingga memerlukan juga akronim. Kebanyakan akronim tidak sesuai dengan wazan yang ada. Akronim dalam bahasa Arab Modern dimanfaatkan untuk membentuk kata dan istilah baru. Secara berturut-turut inilah contoh akronim untuk pembentukan tersebut. ${ }^{37}$

a. Asalnya sudah berupa akronim, contohnya:

\begin{tabular}{|c|c|c|}
\hline $\mathrm{No}$ & Akronim Inggris & Akronim Arab \\
\hline 1 & Electromagnetism & الكهرمغنتية \\
\hline 2 & Electromagnetic Lens & عدسة كهرمغنتية \\
\hline 3 & Hydroelectric & كهرمائى \\
\hline 4 & Electrostatic & كهراكدة \\
\hline 5 & Electrodynamic & كهرينامية \\
\hline
\end{tabular}

b. Pembentukan Akronim dengan memanfaatkan lâ nafi, contohnya adalah sebagai berikut. ${ }^{38}$

\begin{tabular}{|c|c|c|}
\hline No & Kata Bahasa Inggris & Kata Baru Arab \\
\hline 1 & wireless & اللاسلكى \\
\hline 2 & anaerobic & اللاهوائى \\
\hline 3 & amoral & اللأخلاق \\
\hline 4 & anhydrous & اللامائ \\
\hline 5 & unlimited & اللا محدود \\
\hline
\end{tabular}

c. kronim berasal dari Isim, $\underline{H}$ arf, atau Dhamîr contohnya:

\begin{tabular}{|c|c|c|}
\hline $\mathrm{No}$ & Akronim & Asal Kata \\
\hline 1 & اللمية & لمروية \\
\hline 2 & العنعنـة & عن و عن \\
\hline 3 & اليسية & ليس و ياة \\
\hline 4 & قبتاريخ & قبل و تاريخ \\
\hline
\end{tabular}

d. Akronim baina dengan penghilangan nûn dengan kata lain contohnya:

\begin{tabular}{|c|c|}
\hline Kata/Istilah Inggris & Akronim Arab \\
\hline inter-dental & بيأسنانى \\
\hline inter-consonantal & بيصامتى \\
\hline preconsonantal & قبصـامتى \\
\hline prevelar & قبخلقى \\
\hline prevocalic & قبصيائتى \\
\hline
\end{tabular}

${ }^{37}$ Mamduh Muhammad Khasarah. Ilm al-Mushthalabât wa Tharâiq Wadh al-Musthalahât fì al'Arabiyyah.

${ }^{38}$ Chamid Shadiq Qaniby. Al-Ma âjim wa al-Mushthalabât: Mabâhits fî̀ al-Mushthalahât wa al-Ma âjim wa al-Ta rîb. 
Ara6iyât Jurnal Pendidikan Bahasa Arab dan Kebahasaaraban, 4 (2), 2017

e. Berikut ini Akronim pembentukan dengan akronim awal kata, contohnya: ${ }^{39}$

\begin{tabular}{|c|c|}
\hline كهربائى و صوتى & كهرصوتى \\
\hline نزع و قمة & النزقمة \\
\hline نزع و متخ & نزمخـة \\
\hline نزع و ورق & النزورة \\
\hline نزع و طبع & النزطبة \\
\hline
\end{tabular}

f. Berikut ini adalah pembentukan akronim dengan cara lain contohnya:

\begin{tabular}{|c|c|}
\hline إزالة الأكسيد & الزعكدة \\
\hline أوربا و هندى & الروبندى \\
\hline سلب و الترادف & السردفة \\
\hline
\end{tabular}

Dalam perkembangannya kemudian terjadilah pengakroniman dalam berbagai bentuk, yakni, akronim fi'l dengan fi'l, ism dengan ism, harf dan isim, akronim Arabasing maupun asing-Arab.

g. Akronim fi'l dengan fi'l dilakukan untuk untuk membentuk sebuah fi'l baru, seperti:

\begin{tabular}{|c|c|}
\hline شق و حطب & شقحطب \\
\hline بحث و أثارت & بحثرت \\
\hline بعث وثار & بعثر \\
\hline بلغ و غز & بلغز \\
\hline جدب و جرب & جردب \\
\hline
\end{tabular}

h. Adapun akronim ism dengan ism biasanya adalah penggabungan dua buah ism, contohnya adalah sebagai berikut:

\begin{tabular}{|c|c|}
\hline جبة و دراعة & جباعة \\
\hline الجمع و الجمر & الجمعرة \\
\hline الجلع و الجدع & الجلند \\
\hline خل و أماهـة & خلمهة \\
\hline
\end{tabular}

i. Adapun akronim antara $\underline{h}$ arf dan isim, contohnya adalah:

\begin{tabular}{|c|c|}
\hline ملمنايا \\
\hline من المنايا \\
\hline على الرجل \\
\hline علفرس الفرس \\
\hline
\end{tabular}

${ }^{39}$ Nahadi Al-Musa. Al-Naht fì al-Lughah al-'Arabiyyah. (Kairo: Dâr al-'Ilm, 1984), 268. 
Ara6iyât Jurnal Pendidikan Bahasa Arab dan Kebahasaaraban, 4 (2), 2017

j. Ada kalanya akronim ini tidak terdiri dari kata ataupun istilah Arab, namun terjadi na $\underline{b} t$ (akronim) Arab-asing maupun asing-Arab, seperti:

\begin{tabular}{|c|c|}
\hline كهركيميائى & \\
\hline كهبياء و كيميائى & كعديكنتى \\
\hline
\end{tabular}

k. Ditemukan juga akronim yang mengikuti wazan yang ada dalam bahasa Arab. Akronim ini biasanya terjadi pada pembentukan fi'il, yakni dengan memakai wazan fa'lala, contohnya:

\begin{tabular}{|c|c|}
\hline من برق بإزالة القاف و من قال بإزالة الألف & برقل \\
\hline من بلا بإزالة لا و من غز ليس فيه إزالة الحرف & 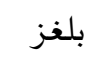 \\
\hline من جرب بإزالة الباء ومن جدب بإزالة الجيم & 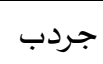 \\
\hline
\end{tabular}

1. Kata baru yang terbentuk dengan cara akronim ini sesudahnya dapat juga dibuat sebagai kata sifat dengan memberikan yâ nisbah, contohnya adalah sebagai berikut.

\begin{tabular}{|c|c|}
\hline أنف و فم & أنفمى \\
\hline حل و كهرباء & حليكهربي \\
\hline خلف و أسنان & خلفيأسنانى \\
\hline شباه الأعمى & الشبعمى \\
\hline الشافعى و أبو حنيفة & شفعنتى \\
\hline
\end{tabular}

m. Akronim dengan mengambil dua bunyi awal dari kata-kata yang dibuat akronim, misalnya: ${ }^{40}$

\begin{tabular}{|c|c|}
\hline الكرة + الضوئية & الضيوكر \\
\hline سلب + جنسية & السلجنة \\
\hline كره + أجنبى & الكرنجـة \\
\hline كهربائى + صوتى & كهرصوتى \\
\hline نزع + قمة & النزقمة \\
\hline
\end{tabular}

n. Akronim yang pembentukannya tidak berpola seperti tersebut di atas, contohnya: ${ }^{41}$

\begin{tabular}{|c|c|}
\hline ازالة الأكسيد & الزعكدة \\
\hline أوربا + هندى & الروبندى \\
\hline سلب + الترادف & السردفة \\
\hline
\end{tabular}

${ }^{40}$ Nahadi Al-Musa. Al-Naht fî al-Lughah al-'Arabiyyah.

41 Nahadi Al-Musa. Al-Nật fî al-Lughah al-'Arabiyyah. 
Demikianlah berbagai kaidah dan peraturan-peraturan yang dikeluarkan oleh lembaga-lembaga bahasa dan para ahli bahasa (rijâl al-lughab). Pembahasan ini sebenarnya merupakan pembahasan yang luas dan dapat diteliti kembali masingmasing bagian secara lebih saksama.

\section{Simpulan}

Bahasa Arab adalah bahasa yang selalu menyesuaikan diri dengan perkembangan ilmu pengetahuan, teknologi, dan seni. Usaha yang dilakukan untuk pembentukan kata dan istilah selalu mengutamakan pembentukan sesuai dengan kaidah yang sudah ada. Ahli-ahli bahasa Arab selalu memanfaatkan kaidah-kaidah yang ada yakni dengan qiyâs. Selanjutnya penciptaan kata dan istilah baru dilakukan juga dengan memanfaatkan wazan-wazan yang telah ada dalam bahasa Arab yakni dengan isytiqâq. Selain itu barulah dilakukan dengan cara terjemahan dari bahasa asing, ta 'rî́b (penyerapan kata dan istilah dengan menyesuaikannya dengan kaidah-kaidah bahasa Arab), tadkhîl (penyerapan kata yang tidak sepenuhnya sesuai dengan kaidah-kaidah bahasa Arab), serta Akronim (naht) yang jarang dilakukan dalam bahasa Arab.]

\section{DAFTAR RUJUKAN}

Al-Anbary, Abdur-Rachman Ibn Muchammad. Al-Inshâf fì Masâilil-Khilâf. Kairo: Darul Fikri, t.t.

Al-Baab, Ja'far Dak. "Al-Shawâmit wa al-Shawâit fî al-'Arabiyyah", Al-Lisanul-Arabi, Nomor 29, 1982.

Al-Musa, Nahadi. Al-Nahbt fí al-Lughah al-'Arabiyyah. Kairo: Dâr al-'Ilm, 1984.

Edi-Subroto, D. Pengantar Metode Penelitian Linguistik Struktural. Sebelas Maret University. Surakarta, 1992.

Hadi, Syamsul. "Perkembangan Mutakbir dalam Babasa Arab" (Pidato Pengukuhan Jabatan Guru Besar pada Fakultas Ilmu Budaya UGM, 2005.

Hadi, Syamsul. Glosarium Kata dan Istilah Asing dalam Babasa Arab. Seksi Penerbitan Jurusan Sastra Asia Barat. FIB. UGM. Yogyakarta, 2005.

Haugen, Einar. Borrowing an Overview dalam William Bright. International Encyclopedia of Linguistics. Oxford University Press. Oxford, 1992.

Hulayyil, Muchammad Chilmy. "Al-Mushthalâhu al-Shautî baina al-Ta'rîb wa alTarjamah”, Al-Lisanul-'Araby, Nomor 21, 1982.

Khasarah, Mamduh Muhammad. 'Tlm al-Mushthalabât wa Tharâiq Wadh al-Musthalabâat fì al-'Arabiyyah. Thabatul Ula, 2008.

Qaniby, Chamid Shadiq. Al-Ma âjim wa al-Mushthalahâat: Mabâhits fì al-Mushthalabâat wa al-Ma `ajim wa al-Ta` rîb. Darus-Suudiyyah lin-Nasyri wat-Tauzi`. Makkah, 2000.

Rachman, F.M. Abdur. Ad-Dakhîl fì al-Lughah al-'Arabiyyah wa Labjâtihâ. Madinah: t.t., 1975.

Az-Zarkan, Muchammad Aly. Al-Jubûd al-Lughawiyyah fî̀ Mushthalâh al-'Tlm al-Hadîts. Mansyurat Ittihad al-Kuttab Al-Arab. Dimasyq, 1994. 